\title{
Священне як стан
}

\section{Михайло Мурашкін, Дніпропетровський державний університет внутрішніх справ}

У статті йдеться про феномен священного як певний стан людини, стан, який притаманний людській природі. Священне розглядається в колі таких категорій і понять, як містичний стан, стан митця, трансцендентність, тиша, алтерність. Священне розуміється як відчуття таємничої сили. Але прослідковано, що ця сила постійно пов'язується з Божественним. Також фіксується зв'язок із трансцендентним. Через трансцендентність помічається зв'язок з певним станом людини, трансовим станом. Але розглядається не який-небудь транс, а компенсаторний. Адже компенсаторний транс цінується людиною, тому що компенсує недоліки. Тому для людини цей вид трансу є священним. Він священний ще й тому, що людина відчуває таємничу силу і абсолютну безстрашність. Компенсаторний транс як священне, сакральне, людина пов'язує з певною релігійною традицією. 3 традицією індуїзму, буддизму, християнства або мусульманства. Але компенсаторний транс як священне є реальним. Це не проста міфологічна проекція, яку означають як Бог. Це реальний стан людського духу. Священне - це той стан людського духу, коли він максимально керує собою, максимально володіє собою. Володіти собою - це раціональний момент у житті людини. При отриманні можливості володіти собою людина переживає трансформації своїх станів, серед яких можна фіксувати Вищий стан, стан священного. У випадку священного - це компенсаторний транс. Особливості цього компенсаторного трансу своїми засобами передає у власній творчості містик, митець, релігійний діяч. Компенсаторний транс може мати прояв у людині й поза усілякою містикою. Але яке то священне, коли воно поза релігією і містикою? Для людини воно священне тому, що компенсує недоліки, полегшує життя.

Ключові слова: священне, містичні стани, мистеитво, трансиендентність, компенсаторний транс

\section{Sacred as a condition}

\section{Michail Murashkin, Dnipropetrovsk State University of Internal Affairs}

The article deals with the phenomenon of the sacred as a certain condition of man, a condition inherent in human nature. The sacred is considered in a circle of such categories and concepts as the mystical state, the state of the artist, transcendence, silence, altarity. The sacred is understood as a sense of mysterious power. But it has been observed that this power is constantly associated with the Divine. The connection with the transcendental is also fixed. Because of transcendence, communication with a certain state of a person, a trans state, is noticed. But it is not considered any trance, but a compensatory one. After all, the compensatory trance is appreciated by man because it compensates for the disadvantages. Therefore, for a person this type of trance is sacred. It is also sacred because one feels a mysterious power and an absolute ferocious fearlessness. Compensatory trance as a sacred, sacred, person associates with a certain religious tradition. With a tradition of Hinduism, Buddhism, Christianity or Mo-Sulmanism. But the compensatory trance as sacred is real. This is not a simple mythological projection, which is referred to as God. This is the real state of the human spirit. The sacred is the state of the human spirit, when it manages the most co-combat, the most possesses itself. Owning yourself is a rational moment in a person's life. Upon receiving the opportunity to possess oneself, a person undergoes the transformation of their states, among which one can record the Higher state, the state of the sacred. In the case of the sacred, it is a compensatory trance. The features of this compensatory trance are conveyed by my own means in my own work, a mystic, an artist, a religious figure. Compensatory trance can have a manifestation in the human melon and beyond all mysticism. But what is sacred when it is outside religion and mysticism? For man, it is sacred because it compensates for the shortcomings and makes life easier.

Keywords: sacred, mystical states, art, transcendence, compensatory trance 


\section{Священное как состояние}

\section{Михаил Мурашкин, Днепропетровский государственный университет внутренних дел}

В статье речь идет о феномене священного как состоянии человека, состоянии, которое присуще человеческой природе. Священное рассматривается в кругу таких категорий и понятий, как мистическое состояние, состояние художника, трансцендентность, тишина, алтерность. Священное пони-мается как чувство таинственной силы. Но прослежено, что эта сила постоянно связывается с Божественным. Также фиксируется связь с трансцендентным. Через трансцендентность замечается связь с определенным состоянием человека, трансовым состоянием. Но рассматривается не какой-нибудь транс, а компенсаторный. Ведь компенсатор-ный транс ценится человеком, потому что компенсирует недостатки. Поэтому для человека этот вид транса является священным. Он священный еще и потому, что человек чув-ствует таинственную силу и абсолютное бесстрашие. Ком-пенсаторный транс как священное, сакральное, человек связывает с определенной религиозной традицией. С традицией индуизма, буддизма, христианства или мусульманства. Но компенсаторный транс как священное является реальным. Это не простая мифологическая проекция, которую обозначают как Бог. Это реальное состояние человеческого духа. Священное - это то состояние человеческого духа, когда он максимально управляет собой, максимально владеет собой. Владеть собой - это рациональный момент в жизни человека. При получении возможности владеть собой человек переживает трансформации своих состояний, среди которых можно фиксировать Высшие состояние, состояние священного. В случае священного - это компенсаторный транс. Особенности этого компенсаторного транса своими средствами передает в своем творчестве мистик, художник, религиозный деятель. Компенсаторный транс может иметь проявление в человеке и вне всякой мистики. Но какое это священное, когда оно вне религии и мистики? Для человека оно священное потому, что компенсирует не-достатки, облегчает жизнь.

Ключевые слова: священное, мистические состояния, искусство, трансиендентность, компенсаторный транс

П остановка проблеми зводиться до того, щоб віднайти стан людини загальний як для містика, так і для митця, розкрити цей стан як священне.

Аналіз досліджень і публікацій показав, що деякі міс-тичні стани як священне вважають притаманними митцям. Так містичні одкровення Джидду Крішнамурті порівнювали 3 даром художника, особливо музиканта (Мери Латьенс).

Мета дослідження зводиться до того, щоб виявити природність стану містика-митця як священне, показати його ту особливість, через яку його називають священним.

Виклад основного матеріалу треба почати 3 окреслен-ня основних категорій, таких як священне, містичний стан, стан митця, трансцендентність, тиша.

Священне. Священне - категорія, яка означає відчуття таємничої сили. До цієї сили людина може ставитися по-різному. Вона може відчувати жах і тремтіти від цієї сили. Вона може сприймати цю силу як чистоту (Джидду Кріш-намурті). Але ця сила захоплює людину. Людина відчуває, що ця сила може зробити іiі щасливою.
Слово «священний» вживається в такому значенні, як «присвячений Богу», «гідний поваги», «піднесений», «величний», «підвищений». За християнським догматом святість - це сутність безкінечної повноти божественного буття, божественної величі. Людина вважається святою, якщо вона пов'язана з Богом, $\epsilon$ «другом Бога» через морально досконале життя.

Тобто священне постійно якось пов'язувалось $з$ Богом. Але Фрідріх Ніцше проголощує смерть Бога. Від того свя-щенне не зникає, не зникає як трансцендентне. Смерть Бога все ж таки залишає можливість існувати трансцендентності, яка посилює значення священного як певного стану свідомості людини.

Трансцендентне можна пов'язати 3 трансом. Адже слово «транс» $\epsilon$ коренем слова «трансцендентний» (В.А. Пус-товаров). А транс, у свою чергу, є певним станом. Хоча видів трансу існує багато. Тому священне можна вважати певним видом трансу. Постає питання, який вид трансу слід вважати священним? Перш за все, це той вид трансу, який людина цінує більш за все. Від того і називає цей транс священним. 
Цінувати людина може більш за все той транс, який їй багато чого дає. Тобто компенсаторний транс. У людини компенсуються недоліки і вирішуються всі проблеми. Нема проблем. I це для людини священне. Такий компенсатор-ний транс людина помічала 3 найпрадавніших часів. Вона розуміла цей транс як Бога. Ще в Рігведі Бог - це багатство, яке ховає недоліки (Ригведа). Тобто в приховуванні недоліків можна бачити компенсаторний процес.

Компенсацію можна розглядати як пристосування функції до нових завдань (А.Н. Леонтьев). Але нові завдання потребують від людини творчого підходу. Транс як компен-саторний процес супроводжує цей творчий підхід. Тому і кажуть про творчість у трансоподібному стані (Б.М. Теплов). Трансоподібний стан - це незвичайний стан у психічному житті людини. Незвичайні психічні стани, які виникають на етапах психічної переадаптації та реадаптації (ейдетизм, екстеріоризаційні реакції, аутизація, психологічна відкритість та інші), ми відносимо до нормальних компенсаторних, захисних психофізіологічних механізмів (В.И. Лебедев). Деякі незвичайні психічні стани людина вважає священними, тому що компенсуються недоліки і людина відчуває полегшення. I це, незважаючи на те, що в нормальному стані компенсація безсвідома (Карл Юнг).

Священне, крім того, що це відчуття таємничої сили, має ще таку характеристику, як повна відсутність страху. Абсолютно немає страху ні перед чим. Стає аж страшно, що $є$ абсолютна безстрашність (М.Г. Мурашкин). Бо коли немає взагалі ніякого страху, і навіть найменших тривог, занепокоєння, хвилювання, людина розуміє, що за таких умов вона не зможе пристосуватися до цього світу, до існування в цьому світі, в оточенні людей. Адже занепокоєння і якесь найменше хвилювання $\epsilon$ стимулом, щоб переборювати i долати перешкоди і перепони. Людина розуміє, що вона не зможе вижити в цьому світі, коли буде мати постійно стан повної відсутності хвилювання, занепокоєння. Тоді вона не буде пристосовуватися, не буде йти на компроміс і буде знищена, увійде в конфлікт з іншими людьми. У мужньої, сміливої людини не така відсут-ність страху. У неї страх $є$. Але вона його пригнічує своєю волею і діє. У неї не така компенсаторна відсутність страху, яка дається компенсаторним трансом. У неї як свідомої людини страх присутній. Але він пригнічений.

Стан священного не перестає існувати в людині, якщо проголосити смерть Бога, як це зробив Фрідріх Ніцше. Тим паче таким чином не можна закрити питання радикальної алтерності.

Алтерність. Алтерність - це коли в межах замкнутої си-стеми щось контролюється, відокремлюється або просто протиставляється. Тобто це іншість. Іншість у межах замкнутої системи.

Людство можна вважати замкнутою системою, яка відрізняється від усього іншого, від високорозвинених тварин і взагалі від природи. У цій замкнутій системі одна людина може повністю не розуміти іншу. Націоналіст, нацист або расист може взагалі не розуміти інтернаціоналіста. Тому купка нацистів або расистів може проводити геноцид того чи іншого народу. Коли немає розуміння іншої людини, то ця інша людина стає для нациста або расиста бездушним предметом, який треба використовувати як заманеться, не врахо-

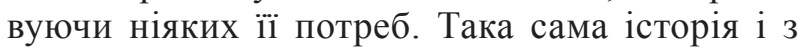
релігійною людиною. Релігійна людина може пережити стан компенсаторного трансу як священне, сакральне, пов'язуючи це переживання 3 певною релігійною традицією. 3 традицією індуїзму, буддизму, християнства або мусульманства. Але ця людина інша. Її можуть не розуміти. Не розуміють ті, хто ніколи в своєму житті не відчував стану компенсаторного трансу, і для нього таке священне або сакральне не існує. Ця людина може бути невіруючою або віруючою. Віруюча людина може зовсім у своєму житті не переживати вищих, особливих станів свідомості, не переживати якихось особливих компенсаторних станів. I тому для неї священним залишається лише те, що людина виконує певний ритуал, виконує маніпуляції якого-небудь обряду. Якщо людина не виконує цього або виконує інші обрядові маніпуляції, то вона незрозуміла і ганебна. Інший - це той, хто робить інші обрядові дійства, не ті ритуальні маніпуляції. А те, що ця людина в своєму суб'єктивному житті пережила вищі стани свідомості, пережила компенсаторний транс як священне, нікого не цікавить. Не цікавить тих людей, які такого не переживали у своєму житті. I для них Бог - це певний комплекс зовнішніх маніпуляцій. Святе Письмо для них - це набір певних правил. А те, що ці правила треба розуміти символічно, бо вони багатозначні, ніяк не сприймається. Кінцевий результат таких взаємодій - одна людина ніяк не сприймає 
іншу людину та її Бога. Хоча за логікою речей Бог - це абсолютний початок. Він Один, Сдиний і тому однаковий для всіх народів, для всіх націй. Таке ніяк не сприймається. I такий Бог виступає як містечковий, для однієї якоїсь нації. А отже, цей Бог задля інтересів цієї нації.

Коли Ісус Христос каже, що перед тим, як був Авраам, Він $\mathcal{C}$, то це обурює іудеїв. Коли людина стверджує «Я $Є$ », то це певний стан засвідчення себе, засвідчення своїх спо-нукань, думок, почуттів і це може привести до компенсаторного стану як священного. Крім того, свідчення себе, спостерігання і споглядання себе, пильнування за собою ми можемо бачити у всілякому Святому Письмі: Ведах, Авесті, Трипітаці, Дао де цзін, Торі, Біблії, Корані. Але це може побачити людина, яка доторкнулась своїм досвідом до компенсаторного трансу як священного. Така людина в словах Ісуса Христа про те, що Він $€$ перед тим, як був Авраам, не побачить ніяких протиріч. А те, що тут порушений часовий інтервал, бо Авраам жив задовго до того, як народився Ісус Христос, то це ніяк не порушує істин. Адже Святе Письмо - це тексти символічні і багатозначні, казкові. А ствердження «Я $€$ » - це певна психічна дія (психотехніка), фіксація свого існування, практика реалізації вищого стану. Про це говорить, наприклад, брахманізм джнана-йоги. Для кожного, яким би шляхом він не йшов, дверима в реальність $\epsilon$ відчуття «Я Є» (Нисаргадатта Махарадж). Через осягнення повного значення «Я Є» $\mathrm{i}$ вихід за його межі до його джерела можливо реалізувати вищий стан (Нисаргадатта Махарадж). Про свідчення, спостерігання i споглядання, про пильнування себе говорить усіляке Святе Письмо. Такий факт дає можливість стверджувати обов'язковість певних правил для різних релігій. Веди кажуть про оживлення життєвих сил і високих сил пильнуючою людиною (Ригведа. Мандала III, 3:7). Авеста теж шанує людину, яка пильнує (Авеста. Яшт:Михр-яшт 10:119). Трипітака теж вказує, що людина повина слідкувати за своїми подумами (Трипитака. Дхаммапада 23. Слон 8:327), схвалює пильнуючу людину (Трипитака. Дхаммапада 2. Бдительность 10:30). Дао де цзін теж мовить про обачливість, незануреність людини (Дао дэ цзин. 26). Тора взагалі каже, що Всесильний свідок (Тора: Брейшит: Ваецэ 31:50). Біблія говорить про те, що Ісус Христос сам свідчить про себе
(Библия. Ин 8:18), про те, що треба постійно спостерігати за собою (Библия. Лук 17:3). Коран теж мовить про свідчення від Бога, коли людина має ясне знамення (Коран. Сура 11. Худ 20:17).

Алтерність Г.В.Ф. Гегеля - це коли «інший» протиста-вляється «я». «Інший» заперечує «я» певної людини. «Я» впізнає себе в іншому. Але впізнає себе поза собою. Свя-щенне залишається, хоча і оголошена смерть Бога, що ніяк не закриває питання радикальної алтерності, а також трансцендентності, тому що розуміння радикальної алтерності й трансцендентності ширше за простір релігійної культури. Священне як таємнича священна сила може торкатися і розглядатися як релігійний містицизм, так і містицизм поза релігією, а також розглядатися як певний прояв людського безсвідомого. Слово «таємниче» у сполучені «таємнича священна сила» вказує на те, що ця священна сила 3'являється в людині невідомо відкіля і через невідомі причини.

Священне як таємнича священна сила насправді є владою, яку здійснює саме суспільство (Emile Durkheim). Священне $є$ реальним. Тобто це не проста міфологічна проек-ція, яку означають як Бог. Це реальний стан людського ду-ху. Але дії в цьому стані від того, що влада, яку здійснює саме суспільство, відображена в людському дусі. Від того людина на момент прояву священного стану виконує лише те, що призначено суспільними відносинами, які мають владу над людиною. У стані священного людина ніби згадує, що їй треба робити далі: що призначено робити (М.Г. Мурашкин). Людина тоді робить лише те, що призначене, покладене, вирішене, ухвалене, установлене владою, яку здійснює саме суспільство через людину, рухаючи дійства людини. Інших дійств у стані священного людина не робить. Робить лише те, що пропонують обставини життя (М.Г. Мурашкин), обставини, які втілює влада. Цю владу здійснює саме суспільство. А людина робить те, що потрібно робити за обставинами, які породжені владою, а отже, і своєю особистою владою, яка керує тілом i всілякими спо-нуканнями.

Священне - це той стан людського духу, коли він мак-симально керує собою, максимально володіє собою. Цей священний стан людина означає тими чи іншими багатоз-начними дивними символами, щоб якось його передати іншій людині. Вигадуються певні 
ритуали, через які може з'явитись можливість іншій людині відчути цей священний стан духу. При цьому враховуються особливості людини. Враховуючи особливості людини, ритуали мають різні медитативні компоненти. С медитація сприймання. $\mathrm{C}$ медита-ція зосередженості. Особливо різні способи медитації де-монструє йога. Для людини дії існує медитація карма-йоги. Для людини розуму і волі існує медитація раджа-йоги. Для емоційної людини - медитація бхакті-йоги. Для інтуїтивної людини - медитація джнані-йоги. Але усіляка медитація зводиться до спостереження за собою. І це повинне бути присутнім у кожному ритуалі. Наприклад, медитація бхакті-йоги це ритмічне повторення мантри або молитви, повторення ритмічних рухів танцю. Але при цьому бхакті-йог повинен спостерігати за собою. Спостерігати, як він повторює мантру або молитву, спостерігати за собою, як він рухається в ритмі танцю.

За вправами релігійно-містичних напрямків ховається раціональне знання про те, як відчути священний стан духу, як оволодіти собою. За своєю суттю людина залежить від колективу, в якому вона існує, від певних законів цього колективу. Деякі з цих законів стають особистими законами для людини. Але ці закони треба виконувати, жити за ними і правилами, які людина встановлює для себе. Поза цими законами у людини багато спонукань. I вона не володіє собою. Для того щоб вона оволоділа собою і отримала стан священного духу, їй треба засвідчувати свої спонукання. Таку медитативну практику як засвідчення своїх спонукань можна знайти у всілякому ритуалізмі релігійно-містичних шкіл і напрямків. Цю медитативну практику ми знаходимо у всілякому Святому Письмі. У Ведах. В Авесті. У Трипітаці. У Дао де цзін. У Торі. У Біблії. У Корані. Бо з цією практикою пов'язана можливість людини оволодіти собою. Володіння собою значно пов'язане 3 можливостями спілкування 3 людьми. Важливою особливістю психіки є здатність відділити своє «я» від зовнішнього середовища, а в більш складних формах психічного - немовби побачити себе збоку. Ця здатність надзвичайно розширює можливості людини в їі спілкуванні з іншими людьми (А.М. Иваницкий). А отже, поширює можливість володіти собою.

Володіти собою - це раціональний момент у житті лю-дини. При отриманні можливості володіти собою людина переживає трансформації своїх станів, серед яких можна фіксувати Вищий стан, стан священного. Тому можна пого-дитись 3 Дюркгеймом, який наголошував на глибинній ра-ціональності віри у священне (Emile Durkheim).

Але володіння собою, раціональність віри у священне зіштовхуються 3 усуненням раціонального, того раціонального, яке не зовсім правильно віддзеркалює змінений зовнішній світ. Священне через таку свою особливість, як ком-пенсаторний транс, тісно пов'язане 3 безсвідомим, з руйнацією тих структур свідомості, які вже віджили своє і не ві-дображають нового в зміненому світі. Про руйнацію віджи-лих структур свідомості говорить містицизм ще 3 прадавніх часів. Центральним символом містицизму $є$ смерть як знак для досвіду, який руйнує попередні структури свідомості (С.С. Аверинцев).Тому руйнація свідомого і раціонального стає обов'язковою при прояві священного. Тоді священне може виступати як нелогічна неоднорідність, що руйнує всеохопні раціональні системи; священне, що дестабілізує полярність суб'єкта-об'єкта. Втягуючи людей у руйнівні контакти, в яких особистості розпадаються в конвульсивному «незнанні» (Georges Bataille). Тут «не-знання» як супроводжуюче священне можна пояснити присутністю компенсаторного трансу в цьому священному. Адже існує посттрансовий ефект амнезії (А.П. Забияко). Це розуміння трансу можна поширити i на компенсаторний транс.

Прояв священного є чисто спонтанним процесом. Тут священна сила зосереджена на принесенні жертви. Але якщо має прояв абсолютна спонтанність, то приносити в жертву можна тільки свій час. Адже, щоб продовжувати в собі священне, людині треба продовжувати дивитись ізсередини себе на свої рухи: рухи рук, рух думки, рух відчуття (М.Г. Мурашкин). Але поглибленість цього процесу зупи-няє усіляку діяльність. Тобто людина в такому разі не діє і відбувається жертва часу; приноситься в жертву час.

Від того, що священне супроводжується компенсаторним трансом, жертва зосереджує містичний досвід. Адже компенсаторний транс входить у містичний досвід як основний компонент. Отже, жертва містить містичний досвід і ще, на думку Ж. Батая, - еротику та письмо (Georges Bataille). 
Є розуміння того, що священне може переплітатися 3 насильством (Rene Girard). Але що ми розуміємо під священним станом? I тут треба мати розуміння, які дії ми вважаємо за священні чи відсутність дій є священною. Насильницькі дії пов'язані з тим, що людина, яка насилує, або гурт людей-насильників переважають у силі, самоволодінні. Так, дійсно, стан священного супроводжується тим, що людина відчуває в собі силу, міць. Священне робить людину скелею (М.Г. Мурашкин). Страх зникає абсолютно (Нисаргадатта Махарадж). Але стан священного - це компенсаторний транс, під час якого тіло людини при певній глибині цього трансу не рухається (Джидду Кришнамурти). Коли людина рухається, то стан священного знижується, а коли людина нерухома - то посилюється (М.Г. Мурашкин). Насильство потребує дій. При посиленному стані священного людина не діє. Вона у спокої. Тому не можна сказати, що насильство і священне переплетені. У стані священного немає насильства. Рух може відбуватися як соціально вмотивований, а не для того, щоб відривати щось для себе і насилувати іншу людину. Та і сам рух відбувається при зниженні сили свя-щенного.

Священне відокремлюється від насильства секуляризованого світу, де немає богів. Але священне намагається ві-докремитись і у сфері Божественного. Там, де зникли боги, поет досі вказує шлях до «святості», яка є слідом богів, що втекли (Martin Heidegger). Тобто священне присутнє і у сфері поетичного мистецтва, і у сфері містичної релігії. I митець та містик переживають подібне. За характеристиками це подібне є компенсаторним трансом. Цей компенсато-рний транс супроводжує священне.

Отже, у містиці та мистецтві можуть бути виражені та описані характеристики священного, яке супроводжується компенсаторним трансом. Деякі містичні стани як священні вважаються притаманними й людям мистецтва. Так, містичне одкровення Джидду Крішнамурті порівнювали 3 даром художника, особливо музиканта (Мери Латьенс). Тобто пе-вні стани містика та митця подібні. Вони подібні, тому що їх подібність робить транс, який супроводжує творчі стани. Адже можна говорити про творчість у трансоподібному стані (Б.М. Теплов). У випадку священ- ного - це компенсаторний транс. Особливості цього компенсаторного трансу своїми засобами передає в творчості як містик, так і митець. Особлива роль в цьому належить ліриці. Адже лірика має витонченість у передачі суперечливих і одиничних психіч-них станів (Лидия Гинзбург). Отже, лірика передає особливі стани свідомості, які складно передати взагалі. До таких станів належить і священне компенсаторного трансу містика і митця. Тому в філософії і загострюється увага на такому понятті як «поетичне священне».

«Поетичне священне» (Martin Heidegger) поза усяким ритуалізмом, поза усякою обрядовістю має свій прояв як певний стан творчого духу людини. Відсутність ритуалізму і обрядовості - фактично виглядає як розпад монотеїстичних релігій. Розпад монотеїстичних релігій як нагода для «повернення божественного» (Luce Irigaray), відкриття «відчутного трансцендентного» (Luce Irigaray) змінює певні моделі трансцендентності, які розпадаються (Luce Irigaray). Те божественне і відчутне трансцендентне нікуди не зникають, бо вони в природі людини як компенсаторний транс. Саме слово «транс» $є$ коренем іншого слова - «трансцендентний» (В.А. Пустоваров). Транс у філософських узагальненнях підіймається до рівня трансцендентності.

Транс буває різний. Але транс, який виступає як священне - компенсаторний транс. Компенсаторний транс може мати прояв у людині й поза усілякою містикою. У такому випадку можна говорити про квазімістичне священне (Jacques Derrida). Тобто нібито містичне, тому що воно має прояв у секулярному світі. Але яке то священне, коли воно поза релігією і містикою? Мабуть, у зв'язку з цим ми маємо заклик покінчити з одержимістю священним, цими «темними околицями скінченності» (Jean-Luc Nancy). Але відлуння священного $є$ у спадщині філософій відмінності (Mark C. Taylor). Тому священного не можна позбавитись. Воно священне для людини, тому що компенсує залежність, стан залежності (М.Г. Мурашкин).

\section{Висновок}

Священне як стан представлене трансовим станом. Але це компенсаторний транс. Він компенсує залежність людини, стан залежності, компенсує недоліки. Тому для людини цей стан священний. 


\section{БІБІЛІОГРАФІЧНІ ПОСИЛАННЯ}

Аверинцев С.С. Мистика // Новая философская энцик-лопедия. В 4 т. Т.2. Москва : Мысль, 2010. С. 579. Авеста / Авеста в русских переводах (1861-1996). Санкт-Петербург : Журнал «Нева». РХГИ, 1997. С. 313. Библия. Книга Священного Писания Ветхого и Нового Завета. Москва : Российское библейское общество, 2011. С. 1116-1138.

Гинзбург Л. О лирике. Москва : Интрада, 1997. С. 226.

Дао дэ цзин / Люйши Чуньцю (Весны и осени господи-на Люя). Москва : Мысль, 2001. С. 464-465. Дхаммапада. Москва : ООО «Издательский дом «Со-фия», 2005. С. 33-131.

Забияко А.П. Транс // Энциклопедия эпистемологии и философии науки. Москва : «Канон» РООИ «Реабилита-ция», 2009. С. 999.

Иваницкий А.М. Изучение причинных связей между физиологическими психическими феноменами при иссле-довании восприятия. Мозг и психическая деятельность. Москва : Наука, 1984. С. 210.

Коран. Москва : Издательско-полиграфическая фирма «АНС-Принт» Ассоциации «Новый стиль», 1990. С. 187.

Кришнамурти Д. Записные книжки. Москва : Разум / Мир Кришнамурти, 1999. С. 200-351.

Латьенс М. Жизнь и смерть Кришнамурти. Москва : «КМК, Лтд», 1993. С. 176.

Лебедев В.И. Личность в экстремальных условиях. Мо-сква : Политиздат, 1989. С. 300.

Леонтьев А.Н. Проблемы развития психики. Москва : Издательство Моск. ун-та, 1981. С. 405.

Мурашкин М.Г. Записи 2000 года. Дніпропетровськ : СІЧ, 2006. С. 122-133.

Нисаргадатта М. Я есть То. Москва : ИД «Ганга», 2013. С. 485-687.

Пустоваров В.А. Путь судьбы. Дніпропетровськ : Поро-ги, 2005. С. 28.

Ригведа: Мандалы I-IV. Москва : Наука, 1989. С. 258-292.

Теплов Б.М. Конспекты и комментарии к книге А. Анастази «Дифференциальная психология» // Избранные труды. В 2т. Т.1. Москва : Педагогика, 1985. С. 268.

Тора. Москва : 5765, 2005. С. 1-190.

Юнг К. Психологические типы. Санкт-Петербург : Ювента; Москва : Издательская фирма «Прогресс-Универс», 1995. С. 532.

Bataille Georges. L'Experience interieure. Paris : Gallimard, 1986.

Derrida Jacques. "Violence et metaphysiqe: essai sur la pensee d'Emmanuel Levinas" in L'Ecriture et la difference. Paris : Seuil, 1967. P. 215-216.

Durkheim Emile. The Elementary Forms of the Religious Life ; trans. Joseph Ward Swain. London : Allen and Unwin, 1915.

Girard Rene. La Violence et le sacre. Paris : Grasset, 1972.

Heidegger, Martin. "What are Poets for?" in Poetry, Language, Thought ; trans. Albert Hofstadter. New York : Harper Colophon, 1971. P. 91.

Irigaray Luce. Ethique de la difference sexuelle. Paris : Minuit, 1984. P. 133-138.

Nancy Jean-Luc. “The Unsacrificeable”. Yale French Studies. 1991. No. 79. PP. 20-38.

Taylor Mark C. Altarity. Chicago: University of Chicago Press.

\section{REFERENCES}

Averintcev, S.S. (2010). Mistika [Mysticism]. New Philosophical Encyclopedia. (Vol.2), (p. 573). Moskva: Mysl [in Russian].

Avesta. (1997). Avesta v russkikh perevodakh (1861-1996) - Avesta in Russian translations (1861-1996). (p. 313). Sankt-Peterburg: Zhurnal "Neva". [in Russian].

Bibliia. Kniga Sviashchennogo Pisaniia Vetkhogo i Novogo Zaveta [Bible. Book of Scripture Old and New Testament]. (2011). (pp. 1116-1138). Moskva: Rossiiskoe bibleiskoe obshchestvo [in Russian].

Ginzburg, L. (1997). O lirike [About the lyrics]. (p. 226). Moskva: Intrada [in Russian].

Liui, Buvei. (2005). Dao de tczin [Tao de jing]. Liuishi Chuntciu (Vesny i oseni gospodina Liuia) - Luishi Chunqiu (Spring and Autumn of Mr. Lu). (pp. 464-465). Moskva: Mysl [in Russian].

Dkhammapada [Dhammapada]. (2005). (pp. 33-131). Moskva: OOO "Izdatelskii dom "Sofiia" [in Russian].

Zabiiako, A.P. (2009). Trans [Trance]. Entciklopediia epistemologii i filosofii nauki-Encyclopedia of Epistemology and Philosophy of Science. (p. 999). Moskva: "Kanon" ROOI "Reabilitatciia" [in Russian].

Ivanitckii, A.M. (1984). Izuchenie prichinnykh sviazei mezhdu fiziologicheskimi psikhicheskimi fenomenami pri issledovanii vospriiatiia [The study of causal relationships between physiological psychic phenomena in the study of perception]. Mozg i psikhicheskaia deiatelnost - Brain and men-tal activity. (p. 210). Moskva: Nauka [in Russian]. Koran. (1990). (p. 187). Moskva: Izdatelsko-poligraficheskaia firma "ANS-Print" Assotciatcii "Novyi stil" [in Russian].

Krishnamurti, D. (1999). Zapisnye knizhki [Notebooks]. (pp. 200-351). Moskva: Razum / Mir Krishnamurti [in Russian].

Latens, M. (1996). Zhizn i smert Krishnamurti [The life and death of Krishnamurti]. (p. 176). Moskva: "KMK, Ltd" [in Russian]. 
Lebedev, V.I. (1989). Lichnost v ekstremalnykh usloviiakh [Extreme personality]. (p. 300). Moskva: Politizdat [in Russian].

Leontev, A.N. (1981). Problemy razvitiia psikhiki [Prob-lems of development of the psyche]. (p. 405). Moskva: Izdatelstvo Mosk. un-ta [in Russian].

Murashkin, M.G. (2006). Zapisi 2000 goda [2000 Notes]. (pp. 122-133). Dnipropetrovsk : SICh [in Russian].

Nisargadatta, M. (2013). Ia est To [I am That]. (pp. 485-678). Moskva: ID "Ganga" [in Russian].

Pustovarov, V.A. (2005). Put sudby [Way of fate]. (p. 28). Dnipropetrovsk: Porogi [in Russian].

Rigveda: Mandaly I-IV [Rigveda: Mandalas I-IV]. (1989). (pp. 258-292). Moskva: Nauka [in Russian].

Teplov, B.M. (1985). Konspekty i kommentarii k knige A. Anastazi "Differentcialnaia psikhologiia" [Summaries and comments on the book of A. Anastazi "Differential Psycholo-gy"]. Izbrannye trudy - Select Works. (Vols. 1), (p. 268). Moskva: Pedagogika [in Russian].

Tora [Torah]. (2005). (pp. 1-190). Moskva: 5765 [in Rus-sian].

Iung, K. (1995). Psikhologicheskie tipy [Psychological types]. (p. 532). Sankt-Peterburg: Iuventa; Moskva : Izdatelskaia firma "Progress-Univers" [in Russian].

Bataille, Georges. (1986). L'Experience interieure. Paris: Gallimard.

Derrida, Jacques. (1967). "Violence et metaphysiqe: essai sur la pensee d'Emmanuel Levinas". In L'Ecriture et la difference. (pp. 215-216). Paris: Seuil.

Durkheim, Emile. (1915). The Elementary Forms of the Religious Life. Joseph Ward Swain (Trans.). London: Allen and Unwin.

Girard, Rene. (1972). La Violence et le sacre. Paris: Grasset.

Heidegger, Martin. (1971). "What are Poets for?". In Poetry, Language, Thought. Albert Hofstadter (Trans.). (p. 91).

New York: Harper Colophon.

Irigaray, Luce. (1984). Ethique de la difference sexuelle. (pp. 133-138). Paris: Minuit.

Nancy, Jean-Luc. (1991). "The Unsacrificeable". Yale French Studies, 79, 20-38.

Taylor, Mark C. (1987). Altarity. Chicago: University of Chicago Press.

\section{Мурашкін Михайло Георгійович}

Доктор філософських наук, професор

Дніпропетровський державний університет

внутрішніх справ

49005, Дніпро, проспект Гагаріна, 26

Email: michailmurashkin@gmail.com

\section{Michail Murashkin}

Doctor of Philosophical Sciences, Full Prof.

Dnipropetrovsk State University of Internal Affairs 26, Gagarin str., Dnipro, 49005, Ukraine

Цитування: Мурашкін М. Г. Священне як стан. Науково-теоретичний альманах «Грані». 2019. Т. 22, № 9-10. С.64-71.

Citation: Murashkin M.G. (2019). Sacred as a condition [Sacred as a condition]. Scientific and theoretical almanac «Grani», 22 (9-10), 64-71. 